\title{
PRODUKSI SINBIOTIK UNTUK MENDUKUNG PENGGUNAAN BAHAN PAKAN LOKAL DALAM BUDIDAYA UNGGAS DAN UDANG
}

\section{SYNBIOTIC PRODUCTION TO SUPPORT THE USE OF LOCAL FEEDSTUFF IN POULTRY AND SHRIMP CULTIVATION}

\author{
Muhamad Ali $^{1}$, Khairil Anwar ${ }^{2}$, Muhammad Aidil Fitriyan Fadjar Suryadi ${ }^{2}$, Muhammad \\ Zubair $^{2}$, Sahrul Alim ${ }^{3}$, Bagus Dwi Hari Setyono ${ }^{4}$, Nefi Andriana Fajri ${ }^{5}$, dan Muhamad \\ $\operatorname{Amin}^{6 * 1}$ \\ ${ }^{1}$ Laboratorium Mikrobiologi dan Bioteknologi, Fakultas Peternakan Universitas Mataram \\ 2Program Studi Peternakan, Fakultas Peternakan Universitas Mataram \\ ${ }^{3}$ Program Studi Budidaya Perikanan, Program Vokasi Universitas Mataram di Kabupaten \\ Lombok Utara \\ ${ }^{4}$ Program Studi Budidaya Perairan, Fakultas Pertanian, Universitas Mataram \\ ${ }^{5}$ Fakultas Peternakan, Universitas Nahdlatul Wathan Mataram \\ ${ }^{6}$ Departemen Manajemen Kesehatan Ikan dan Budidaya Perairan, Fakultas Perikanan dan \\ Kelautan, Universitas Airlangga Surabaya.
}

Jalan Dharmahusada Permai No. 330, Kota Surabaya, Provinsi Jawa Timur, 60115

*Alamat korespondensi: muhamad.amin@fpk.unair.ac.id

(Tanggal Submission: 11 Maret 2020, Tanggal Accepted: 15 April 2020)

\begin{abstract}
ABSTRAK
Pakan merupakan salah satu faktor yang menentukan keberhasilan budidaya ternak unggas dan udang. Permasalahan utama yang dihadapi oleh budidaya kedua komiditas tersebut adalah tingginya biaya pakan. Solusi yang ditawarkan untuk mengatasi permasalahan tersebut adalah optimalisasi penggunaan bahan lokal yang didukung oleh penggunaan sinbiotik. Sinbiotik merupakan kombinasi antara probiotik dan prebiotik yang dapat memberikan manfaat bagi peningkatan kecernaan pakan serta keseimbangan mikroorganisme saluran pencernaan ternak unggas dan udang untuk kesehatan. Unggas yang dimaksudkan adalah ayam petelur, sementara udang yang dmaksud adalah udang vannamei. Tujuan dari kegiatan pengabdian ini adalah untuk meningkatkan pemahaman dan keterampilan peternak unggas dan udang dalam memproduksi sinbiotik sebagai campuran pakan berbahan baku lokal. Kegiatan pengabdian ini dilaksanakan di Desa Pijot Kecamatan Keruak Kabupaten Lombok Timur Provinsi Nusa Tenggara Barat. Metode yang digunakan pada kegiatan pengabdian ini adalah pelatihan pembuatan sinbiotik dan uji palatabilitas sinbiotik pada ternak unggas dan udang. Pelatihan pembuatan probiotik menyangkut penentuan jumlahdan jenis bahan baku sinbiotik, pencampuran probiotik dan prebiotik, pembuatan pellet (pelleting) dan proses pengeringan. Untuk mengetahui tingkat palatabilitas pada unggas dan udang, sinbiotik yang sudah dihasilkan diberikan ke ternak unggas dan udang. Penggunaan sinbiotik pada campuran pakan ternak unggas dan udang dapat mengurangi biaya pakan sehingga peternak mendapatkan keuntungan yang lebih tinggi. Kesimpulan dari kegiatan pengabdian ini adalah peternak dapat menerima inovasi dengan baik, mampu mempersiapkan bahan baku dan melaksanakan proses pembuatan sinbiotik.
\end{abstract}

Keywords: pakan, sinbiotik, ternak unggas, udang, probiotik. 


\section{PENDAHULUAN}

Budidaya ternak unggas dan udang di Indonesia semakin berkembang karena dituntut oleh kebutuhan masyarakat dan mempunyai peluang usaha yang menguntungkan. Menurut Wardhany et al. (2017) ayam petelur mampu memproduksi telur kisaran 250-280 butir per tahun. Widaningsih et al. (2017) menambahkan bahwa dalam kurun waktu 2016-2021 secara ratarata produksi telur ayam ras meningkat 4,46 persen per tahun. Produksi tersebut dapat mencukupi kebutuhan konsumsi masyarakat Indonesia yaitu telur selama kurun waktu 2016-2021 secara ratarata meningkat 3,04 persen per tahun. Disamping itu, budidaya udang mengalami perkembangan yang sangat pesat karenakan keunggulan yang dimilikinya, diantaranya memililiki kemampuan adaptasi yang relatif tinggi terhdapat perubahan lingkungan, memiliki tingkat responsitf terhadap pakan yang diberikan dan memiliki pemasaran yang baik pada skala internasional (Kurniawan et al. 2016).

Pakan merupakan salah satu faktor yang menentukan keberhasilan pada budidaya ternak unggas dan udang (Hardianti, 2017). Menurut Sari et al. (2014) biaya produksi pada budidaya ternak unggas yang paling tinggi adalah biaya pakan yakni 60-80 persen dari seluruh komponen biaya produksi yang dikeluarkan, sedangkan menurut Kurniawan et al. (2016) biaya pakan pada budidaya udang mencapai 50-60 persen dari total biaya produksi. Tingginya biaya operasional untuk pengadaan pakan menjadi salah satu permasalahan yang dihadapi oleh peternak unggas dan udang di Pesisir Pantai Selayar, Kecamatan Kruak, Kabupaten Lombok Timur. Bahan baku pakan ternak unggas dan udang sebagian besar merupakan bahan baku yang diperoleh dengan cara impor dari luar negeri. Penggunaan bahan baku lokal sebagai pengganti bahan baku pakan impor memberikan kontribusi besar dalam pengembangan peternakan unggas dan udang.

Dedak padi dan limbah penetasan telur merupakan limbah lokal yang dapat dijadikan sebagai bahan baku pakan untuk ternak unggas dan udang. Produksi padi di Provinsi Nusa Tenggara Barat mencapai 1.399.495 ton gabah kering per tahun dengan potensi dedak padi yang dihasilkan mencapai 111.960-279.899 ton/tahun (BPS, 2018). Menurut Utami (2011) dedak padi mengandung bahan kering 88,93 persen, protein kasar 12,39 persen, serat kasar 12,59 persen, kalsium 0,09 persen dan pospor 1,07 persen. Dedak padi mempunyai ketersediaan yang cukup melimpah, harga relatif lebih murah dan tidak bersaing dengan kebutuhan manusia (Wibawa et al., 2015).

Penggunaan dedak padi sebagai campuran pakan sebaiknya disuplementasi dengan bahan lain. Salah satu bahan yang dapat digunakan sebagai suplementasi adalah limbah penetasan telur. Menurut Indreswari dan Adi (2017) limbah penetasan telur mempunyai kandungan nutrisi yang cukup baik yaitu protein kasar 36,2 persen, lemak kasar 23,9 persen, serat kasar 0,9 persen, abu 25,1 persen, energi metabolisme (EM) 2.795,2 $\mathrm{kkal} / \mathrm{kg}$, kalsium 25,62 persen dan pospor 1,47 persen.

Kedua bahan pakan tersebut dapat dibuat sebagai pakan alternatif untuk ternak unggas dan udang. Dedak padi dan limbah penetasan telur dapat diolah menjadi sinbiotik. Sinbiotik merupakan kombinasi antara probiotik dan prebiotik yang dapat memberikan manfaat bagi kesehatan dan menjaga keseimbangan mikrobium saluran pencernaan ternak unggas dan udang (Watson and Preedy, 2016). Sinbiotik dari bahan lokal tidak hanya bermanfaat untuk kesehatan ternak unggas dan udang tetapi memberikan manfaat secara ekonomi karena sinbiotik dapat digunakan sebagai campuran pakan sehingga dapat mengurangi biaya pakan.

Tujuan dari kegiatan pengabdian ini adalah untuk meningkatkan pemahaman dan keterampilan peternak unggas dan udang dalam memproduksi sinbiotik sebagai campuran pakan ternak unggas dan udang.

\section{METODE KEGIATAN}

\section{Waktu dan Tempat}

Kegiatan pengabdian ini dilaksanakan di Desa Pijot, Kecamatan Keruak, Kabupaten Lombok Timur, Provinsi Nusa Tenggara Barat pada tanggal 25 Agustus sampai tanggal 7 September 2019.

\section{Alat dan Bahan}

Alat yang digunakan adalah mesin pencetak pellet, oven (pengering), ember, alat semprot, terpal dan karung. Sedangkan bahan yang 
digunakan adalah dedak padi, limbah penetasan telur, probiotik, dan air bersih.

\section{Bentuk Kegiatan}

Metode yang digunakan pada kegiatan pengabdian ini adalah 1) penyuluhan teknis, 2) kegiatan praktik pembuatan sinbiotik dan 3) uji palatabilitas sinbiotik pada ternak unggas dan udang. Penyuluhan teknis memaparkan tentang bahan baku sinbiotik, menghitung kebutuhan, penimbangan, pencampuran probiotik dan prebiotik, pembuatan pellet (pelleting) dan proses pengeringan. Sinbiotik yang sudah berbentuk pellet diberikan ke ternak unggas dan udang untuk mengetahui tingkat palatabilitasnya.

\section{Prosedur Pembuatan Pellet Sinbiotik}

Pembuatan sinbiotik meliputi beberapa tahapan diantaranya: 1) mempersiapkan bahan baku sinbiotik (probiotik dan prebiotik), 2) menimbang dedak padi, 3) mengukur volume limbah penetasan telur, 4) mencampurkan dedak padi dengan limbah penetasan telur kemudian melakukan proses pengukusan, 5) mengeringkan prebiotik, 6) mengukur jumlah probiotik, 7) mencampur probiotik dengan prebiotik, 8) pembuatan pellet (pelleting), 9) mengeringkan sinbiotik menggunakan oven, 10) pengemasan pellet sinbiotik, 11) uji kandungan nutrisi sinbiotik, 12) uji palatabilitas pellet sinbiotik pada ternak unggas dan udang.

\section{HASIL DAN PEMBAHASAN}

\section{Pembuatan Pellet Sinbiotik}

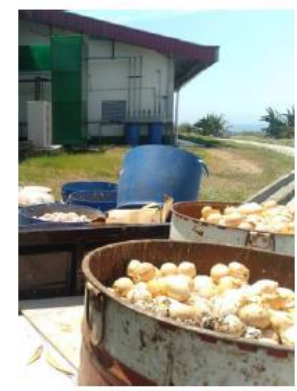

Telur Infertil

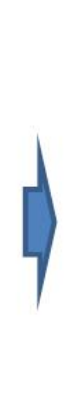

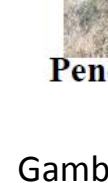

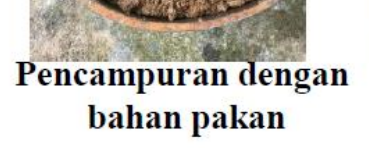

Limbah penetasan telur yang berupa telur infertil dipecahkan untuk diambil isi telur. Pencampuran dilakukan dengan bahan-bahan
Program pengabdian masyarakat yang dilakukan di Desa Pijot, Kecamatan Keruak, Kabupaten Lombok Timur, Provinsi Nusa Tenggara Barat terlaksana secara terstruktur dengan melibatkan peternak ayam kampung dan udang secara langsung. Kegiatan pengabdian ini diikuti oleh beberapa peternak ayam kampung dan udang yang sudah lama mengembangkan usahanya tetapi terkendala biaya operasional pakan yang terlalu tinggi.

Kegiatan pengabdian ini diawali dengan penyuluhan tentang pentingnya pakan yang memenuhi kebutuhan nutrisi pada budidaya ayam kampung dan udang. Melalui pengabdian ini peternak didorong untuk mengembangkan usahanya dengan memanfaatkan bahan-bahan lokal yang mudah diperoleh, harga murah, dan tersedia secara kontinyu. Untuk itu, jenis bahanbahan lokal yang digunakan sebagai pakan diantaranya dedak padi, jagung dan limbah penetasan telur sebagai bahan baku pembuatan sinbiotik.

Dedak padi dan jagung merupakan sumber energi yang tersedia di tingkat peternak dengan harga terjangkau. Pada dedak padi dan jagung terdapat bahan-bahan yang sulit dicerna oleh ayam maupun udang sehingga dapat berperanan sebagai prebiotik untuk digunakan oleh probiotik. Sedangkan limbah penetasan telur, terutama telur infertil, merupakan sumber protein yang sangat diperlukan di dalam pakan. Proses pembuatan sinbiotik dari bahan-bahan lokal yang mudah diperoleh tersebut ditunjukkan pada Gambar 1.
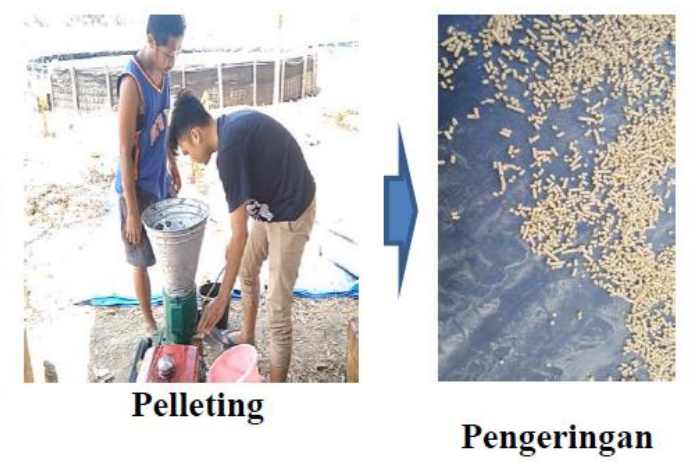

pakan (dedak padi, jagung, dan bahan-bahan lain) untuk kemudian disemprot dengan probiotik. Probiotik yang digunakan terdiri dari bakteri asam 
laktat yang memiliki kemampuan memcah pati, selulosa dan asam fitat. Setelah pencampuran dilanjutkan dengen pembuatan pelet untuk kemudian dilakukan pengeringan. Produk sinbiotik yang dihasilkan dapat dilihat pada Gambar 2.

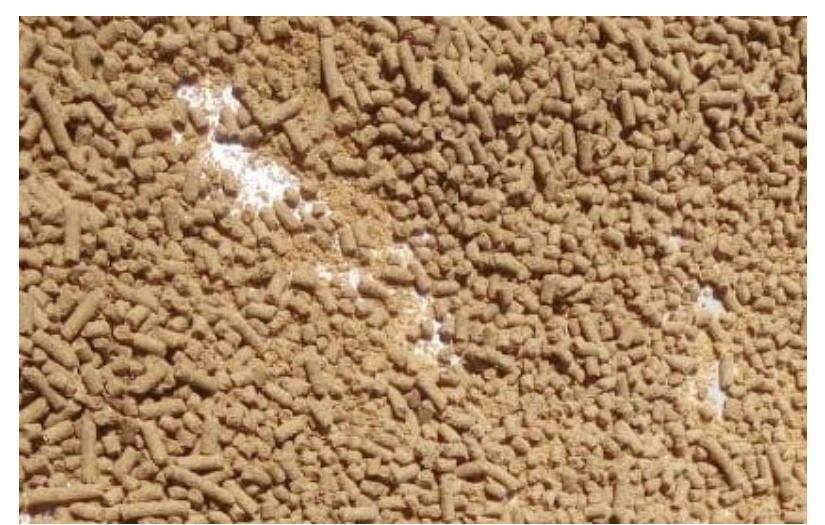

Gambar 2. Pellet sinbiotik

Produk sinbiotik mempunyai pengaruh yang sinergis dalam perkembangbiakan dan daya hidup bakteri probiotik di dalam saluran pencernaan inang (Tang et al., 2017). Pemberian sinbiotik mampu meningkatkan kinerja usus dan kecernaan nutrisi dengan meningkatnya jumlah mikroflora usus yang menguntungkan, menghasilkan asam rantai pendek di dalam duodenum, jejenum dan meningkatkan jumlah vilivili usus untuk memaksimalkan proses penyerapan nutrisi (Gomez-Alcon et al., 1990). Penggunaan sinbiotik memberikan respon molekuler terhadap sistem kekebalan tubuh (sistem imun).

Probiotik yang digunakan pada pembuatan sinbiotik mengandung bakteri asam laktat dan Bacillus spp. yang mempunyai banyak manfaat dalam menjaga kesehatan dan meningkatkan produktivitas ternak unggas dan udang. Bakteri yang digunakan pada pembuatan sinbiotik merupakan bakteri dengan viabilitas cukup baik dan tahan terhadap proses pengeringan. Pengeringan bertujuan untuk mengurangi kadar air pada pellet sinbiotik sehingga memungkinkan dapat disimpan dalam jangka waktu yang cukup lama. Kadar air pakan yang rendah mempunyai daya simpan yang lebih lama dibandingkan pakan dengan kadar air yang tinggi (Hall, 1980; Purnamasari et al., 2016). Standar kadar air pakan untuk proses penyimpanan tidak boleh melebihi 14\% (SNI, 2015). Dalam kondisi kering, beberapa bakteri yang digunakan dalam pembuatan sinbiotik masih mampu bertahan dengan menghasilkan endospora. Genus bakteri Bacillus spp. merupakan salah satu bakteri yang mampu membentuk endospora yang tahan terhadap panas (Pelczar et al. 1976).

\section{Kandungan Nutrisi Pellet Sinbiotik}

Penggunaan dedak padi dan limbah penetasan telur sebagai prebiotik mempunyai keuntungan karena dapat menyediakan zat nutrisi yang lebih lengkap untuk pertumbuhan bakteri probiotik serta untuk ayam petelur. Dedak padi mengandung serat kasar yang tinggi yang merupakan karbohidrat tidak tercerna yang dapat merangsang pertumbuhan dan aktivitas bakteri probiotik. Kombinasi dedak padi dengan limbah penetasan telur diharapkan dapat meningkatkan kecernaan bahan dan kandungan nutrisi sinbiotik.

Hasil analisis kandungan nutrisi sinbiotik menunjukan bahwa sinbiotik layak digunakan sebagai pakan imbuhan untuk ayam petelur karena kandungan nutrisinya yang cukup baik. Kadar bahan kering yang tinggi $(92,16 \%)$ memungkinkan untuk penyimpanan sinbiotik dalam waktu yang cukup lama. Kadar bahan kering mempunyai korelasi terbalik dengan kadar air, semakin tinggi kadar bahan kering maka kadar airnya akan semakin rendah. Berdasarkan data diatas, dapat diperoleh kadar air sinbiotik sebesar 7,84\%. Kadar air tersebut sudah layak untuk proses penyimpanan (SNI, 2015).

Sinbiotik yang disuplementasi limbah penetasan telur mempunyai kandungan protein kasar sebesar $19,45 \%$. Penambahan probiotik dan limbah penetasan telur pada dedak padi dapat meningkatkan kandungan protein kasarnya. Hasil penelitian sebelumnya dilakukan oleh Wibawa et al., (2015) melaporkan bahwa penambahan 0,2\% dan $0,4 \%$ probiotik dapat meningkatkan kandungan protein kasar dedak padi dari 10,93\% menjadi $13,1 \%$ dan $13,27 \%$. Data hasil penelitian diperoleh kandungan protein kasar pada sinbiotik suplementasi limbah penetasan telur lebih tinggi dibandingkan dengan dedak fermentasi biasa. Meningkatnya kandungan protein kasar disebabkan adanya pengaruh dari limbah penetasan telur dan bakteri probiotik.

Rasool et al. (1999) menjelaskan bahwa kandungan protein pada limbah penetasan telur mempunyai protein dan kecernaan tinggi mencapai $86 \%$ serta mempunyai asam-asam amino yang seimbang sehingga suplementasi dedak padi 
dapat mempengaruhi kandungan protein kasarnya. Selain adanya suplementasi limbah penetasan, peningkatan kandungan protein sinbiotik dipengaruhi oleh keberadaan bakteri probiotik. Landecker (2001) menjelaskan bahwa bakteri probiotik akan mengubah senyawa-senyawa kompleks yang ada di dalam substrat untuk pertumbuhan dan pembentukan protein selnya. Senyawa kompleks diubah menjadi senyawa yang lebih sederhana sehingga mudah dicerna oleh ternak. Peningkatan kandungan protein pada sinbiotik karena adanya sisa-sisa sel mikroba yang sudah mati. Peningkatan kandungan protein merupakan refleksi dari jumlah massa sel fermentor (Muhiddin et al., 2000).

Kadar protein kasar $(19,45 \%)$ yang cukup tinggi pada sinbiotik memungkinkannya dapat digunakan sebagai substitusi bahan pakan sumber protein untuk ayam petelur. Keuntungan lain yang diperoleh yaitu semakin berkurangnya biaya pengadaan pakan karena bahan-bahan baku untuk pembuatan sinbiotik berasal dari bahan baku lokal yang mudah diperoleh dan mempunyai harga yang relatif lebih murah dibandingkan bahan pakan lainnya.

Sinbiotik yang disuplementasi limbah penetasan telur mempunyai kandungan serat kasar sebesar $12,04 \%$. Hasil penelitian sebelumnya yang dilakukan oleh Wizna dan Muiz (2012) melaporkan bahwa dedak padi yang difermentasi menggunakan Bacillus amyloliquefaciens mengalami penurunan serat kasar dari $12,00 \%$ menjadi $7,56 \%$. Hasil penelitian sebelumnya lebih baik yang disebabkan proses fermentasinya lebih lama. Wizna et al. (2007) menjelaskan bahwa probiotik dari jenis bakteri Bacillus amyloliquefaciens mampu menghasilkan enzim selulase dan hemiselulase yang berfungsi untuk menghidrolisis selulosa dan hemiselulosa.

Kelemahan dari sinbiotik yang dihasilkan adalah masih terdapat kadar serat kasar dan abu yang tinggi masing-masing $12,04 \%$ dan $21,72 \%$. Tingginya kadar serat kasar dan abu pada sinbiotik menyebabkan sinbiotik tidak dapat digunakan secara penuh sebagai pakan ayam petelur. Sinbiotik dapat digunakan sebagai campuran dari bahan baku pakan ayam petelur dengan batas maksimal $50 \%$ dari jumlah pakan yang dibuat.

\section{Uji Palatabilitas Pellet Sinbiotik Pada Ternak Unggas dan Udang}

Uji palatabilitas dilakukan untuk mengetahui tingkat palatabilitas pellet sinbiotik pada ternak unggas dan udang. Sinbiotik diuji secara langsung menggunakan teknik in vivo yaitu uji dilakukan pada ternak unggas dan udang. Pellet sinbiotik yang diberikan ke ternak unggas disukai yang ditunjukan dengan tingkah laku unggas (behavior) dalam mematuk pellet sinbiotik. Uji palatabilitas pada ternak unggas ditampilkan pada Gambar 3.

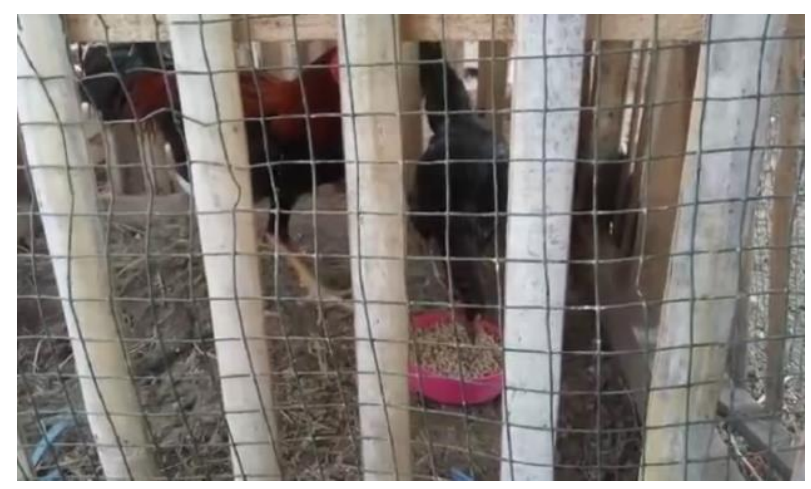

Gambar 3. Uji palatabilitas pellet sinbiotik pada ternak unggas

Pellet sinbiotik selanjutnya diuji tingkat palatabilitasnya pada udang. Uji dilakukan dengan cara memasukan pellet sinbiotik ke dalam jaring yang biasa digunakan untuk memeriksa kondisi pakan pada udang. Setelah pellet sinbiotik diletakkan ke dalam jaring kemudian dibiarkan selama 1 jam. Apabila banyak udang pada jaring dan pellet sinbiotik habis, maka pellet sinbiotik diasumsikan disukai oleh udang. Uji palatabilitas pellet sinbiotik pada udang dijelaskan pada Gambar 4.

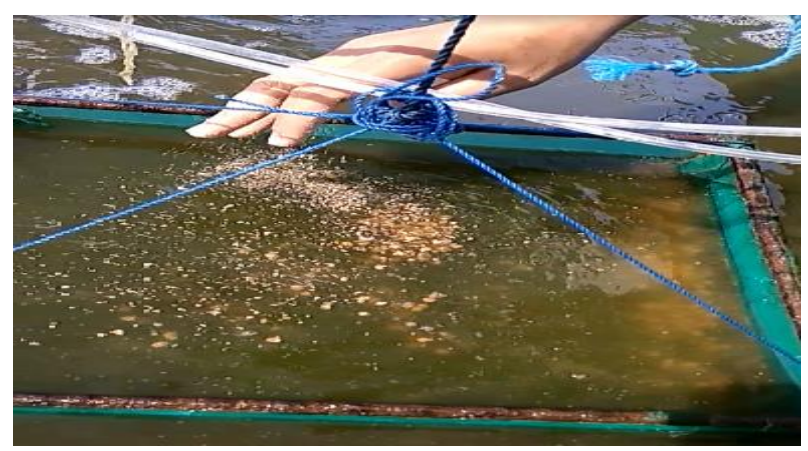




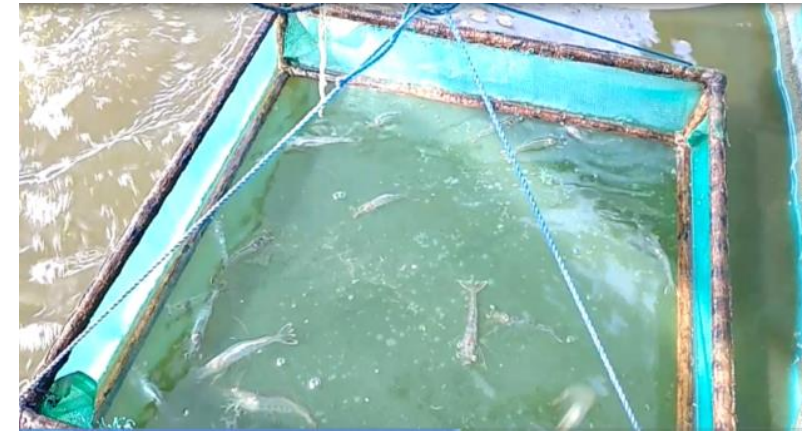

Gambar 4. Uji palatabilitas pellet sinbiotik pada udang

\section{Manfaat Penggunaan Pellet Sinbiotik}

Penggunaan pellet sinbiotik pada ternak unggas dan udang dapat memberikan manfaat terhadap kualitas kesehatan, menjaga keseimbangan mikrobium saluran pencernaan, merangsang respon imun, mencegah infansi bakteri patogen, meningkatkan efisiensi penggunaan pakan, meningkatkan kesehatan dan meningkatkan produktivitas. Secara ekonomi, penggunaan pellet sinbiotik pada ternak unggas dan udang dapat mengurangi biaya pakan karena sinbiotik diproduksi dengan bahan baku lokal yang mudah didapat, ketersediaan melimpah dan harga relatif murah. Berkurangnya biaya pakan tentu akan meningkatkan jumlah pendapatan dari peternak unggas dan udang sehingga dapat meningkatkan kesejahteraan peternak.

\section{KESIMPULAN DAN SARAN}

Kegiatan pengabdian ini telah mendorong peternak unggas dan udang menghasilkan pellet sinbiotik berbahan baku lokal guna mengatasi permasalahan biaya pakan yang terlalu tinggi. Pellet sinbiotik mempunyai kandungan nutrisi yang cukup baik dan penggunaannya dapat mengurangi biaya pengadaan pakan.

Saran yang disampaikan yaitu sebaiknya bakteri probiotik yang ada di dalam sinbiotik diuji seberapa lama daya tahan hidupnya di dalam sinbiotik.

\section{UCAPAN TERIMAKASIH}

Penulis mengucapkan terimakasih kepada Kementerian Riset, Teknolog, dan Pendidikan Tinggi yang telah memberikan dukungan finansial terhadap kegiatan pengabdian ini melalui skim Program Kemitraan Wilayah (PKW) tahun anggaran
2019. Demikian pula kepada Badan Perencanaan Pembangunan Daerah Provinsi Nusa Tenggara Barat yang telah memberikan dana pendampingan.

\section{DAFTAR PUSTAKA}

Gomez-Alcon, R. A., Dudas, C., Huber, J. T.,1990. Influence of cultures of Aspergillus oryzae on rumen and tract digestibility of dietary component. J. Dairy Sci. 73: 703-710.

Hall, C. W. 1980. Drying and Storage of Agricultural Crops. The AVI Publishing Co, Inc. Westport, Connecticut.

Hardianti, M., Sulistiyanto B. dan Sumarsih S. 2017. Pengaruh Penambahan Bentonit pada Proses Pelleting Limbah Penetasan terhadap Kandungan Nutrisi Produk Pelet Pasca-Penyimpanan. Prosiding Seminar Nasional Teknologi Peternakan dan Veteriner. 664-670.

Indreswari, R. dan Adi R. 2017. Aplikasi Tepung Limbah Penetasan dalam Ransum untuk Meningkatkan Produktivitas Itik Lokal di Kelompok Ternak Desa Gaum, Kecamatan Tasikmadu, Kabupaten Karanganyar. Jurnal SEMAR.5 (2).

Kurniawan, L. A., Muhammad A., Abdul M. dan Daruti D N. 2016. Pengaruh Pemberian Probiotik Berbeda pada Pakan terhadap Retensi Protein dan Retensi Lemak Udang Vaname (litopenaeus vannamei). Journal of Aquaculture and Fish Healt. 6 (1).

Landecker, E. M., 2001. Fundamentals of the Fungi. Prentice Hall International Inc. New Jersey.

Muhiddin, N. N. Juli, dan I. N. P. Aryantha. 2000. Peningkatan Kandungan Protein Kulit Umbi Ubi Kayu Melalui Proses Fermentasi. Jurnal Matematika dan Sains. 6 (1) : 1-12.

Pelczar, M. J., E. C. S. Chan, and N. R. Krieg. 1976. Microbiology. Me Graw Hill Book Company. New York.

Purnamasari, D. K., Erwan, Syamsuhaidi, M. Kurniawan. 2016. Evaluasi Kualitas Pakan Komplit dan Konsentrat Unggas yang Diperdagangkan di Kota Mataram. Jurnal Peternakan Sriwijaya. 5 (1): 30-38.

Rasool, S., M. Rehan, A. Haq and M. Z. Alam. 1999. Preparation and nutritional evaluation of hatchery waste meal for broilers. AsianAustralasian Journal Animal Science. 12: 554-557. 
Sari, D. T. I., Sudjarwo, E. dan Prayogi, H. 2014. Pengaruh Penambahan Cacing Tanah (Lumbricusrubellus) Segar dalam Pakan terhadap Berat Telur, Haugh Unit (HU) dan Ketebalan Cangkang Itik Mojosari. J. Ternak Tropika. 15 (2): 23-30.

Sari, M. L. dan F. Gurki N. G. 2012. Pengaruh Penambahan Enzim Fitase pada Ransum terhadap Berat Relatif Organ Pencernaan Ayam Broiler. Agripet. 12 (2): 3-41.

Standar Nasional Indonesia (SNI). 2015. Pakan Untuk Ayam Ras Pedaging (Broiler Starter). www.bsn.go.id. [Diakses 2 September 2019].

Tang, S. G. H., C. C. Sieo, K. Ramasamy, W. Z. Saad, H. K. Wong, Y. H. Ho. 2017. Performance, Biochemical and Haematological Responses, and Relative Organ Weights of Laying Hens Fed Diets Supplemented with Prebiotic, Probiotic and Synbiotic. BMC Veterinary Research. 13 (248) 2017: 1-12.

Utami, Y. 2011. Pengaruh imbangan feed suplemen terhadap kandungan protein kasar, kalsium dan fosfor dedak padi yang difermentasi dengan Bacillus amyloliquefaciens. Skripsi. Fakultas PeternakanUniversitas Andalas. Padang.

Watson, R. R. and V. R. Preedy. 2016. Probiotics, Prebiotics, and Synbiotics Bioactive Foods in Healts Promotion. Elsevier Inc. London, United Kingdom.

Wardhany, B. A. K., Imam C. dan Edy S. 2017. Penentuan Komposisi Pakan Ternak untuk Memenuhi Kebutuhan Nutrisi Ayam Petelur dengan Biaya Minimum Menggunakan Particle Swarm Optimization (PSO). Malang. Jurnal Pengembangan Teknologi Informasi dan Ilmu Komputer. 1 (12): 1642-1651.

Wibawa A. A. P., Wirawan I. W. dan Partama I. B. G. 2015. Peningkatan Nilai Nutrisi Dedak Padi sebagai Pakan Itik melalui Biofermentasi dengan Khamir. Majalah Ilmiah Peternakan. 19 (1): 41-46.

Widaningsih, R. 2017. Outlook Telur. Pusat Data dan Sistem Informasi Pertanian Sekretariat Jenderal Kementerian Pertanian.

Wizna, H., Y. Abbas, Rizal, A. Dharma dan I. P. Kompiang. 2007. Selection and identification of cellulase-producing bacteria isolated from the litter of mountain and swampy forest. J. Microbiology Indonesia. 1 (3): 135-139.

Wizna dan H. Muiz. 2012. Pemberian Dedak Padi yang Difermentasi dengan Bacillus amyloliquefaciens sebagai Pengganti Ransum Komersial Ayam Ras Petelur. Jurnal Peternakan Indonesia. 14 (2): 398403. 